\title{
Oral biofilm models for mechanical plaque removal
}

\author{
Martinus J. Verkaik • Henk J. Busscher • \\ Minie Rustema-Abbing • Anje M. Slomp • \\ Frank Abbas $\cdot$ Henny C. van der Mei
}

Received: 27 February 2009 / Accepted: 15 June 2009 /Published online: 30 June 2009

(C) The Author(s) 2009. This article is published with open access at Springerlink.com

\begin{abstract}
In vitro plaque removal studies require biofilm models that resemble in vivo dental plaque. Here, we compare contact and non-contact removal of single and dual-species biofilms as well as of biofilms grown from human whole saliva in vitro using different biofilm models. Bacteria were adhered to a salivary pellicle for $2 \mathrm{~h}$ or grown after adhesion for $16 \mathrm{~h}$, after which, their removal was evaluated. In a contact mode, no differences were observed between the manual, rotating, or sonic brushing; and removal was on average $39 \%, 84 \%$, and $95 \%$ for Streptococcus mutans, Streptococcus oralis, and Actinomyces naeslundii, respectively, and $90 \%$ and $54 \%$ for the dualand multi-species biofilms, respectively. However, in a non-contact mode, rotating and sonic brushes still removed considerable numbers of bacteria $(24-40 \%)$, while the manual brush as a control (5-11\%) did not. Single $A$. naeslundii and dual-species (A. naeslundii and $S$. oralis) biofilms were more difficult to remove after $16 \mathrm{~h}$ growth than after $2 \mathrm{~h}$ adhesion (on average, $62 \%$ and $93 \%$ for 16 and 2-h-old biofilms, respectively), while in contrast, biofilms grown from whole saliva were easier to remove ( $97 \%$ after $16 \mathrm{~h}$ and $54 \%$ after $2 \mathrm{~h}$ of growth). Considering the strong adhesion of dual-species biofilms and their easier more reproducible growth compared with biofilms grown from whole saliva, dual-species biofilms of $A$. naeslundii
\end{abstract}

\footnotetext{
M. J. Verkaik · H. J. Busscher - M. Rustema-Abbing •

A. M. Slomp $\cdot$ H. C. van der Mei $(\bowtie)$

Department of Biomedical Engineering, University Medical

Center Groningen and University of Groningen,

P. O. Box 196, Groningen 9700 AD, The Netherlands

e-mail: h.c.van.der.mei@med.umcg.nl

F. Abbas

Center for Dentistry and Oral Hygiene, University Medical Center

Groningen and University of Groningen,

Groningen, The Netherlands
}

and $S$. oralis are suggested to be preferred for use in mechanical plaque removal studies in vitro.

Keywords Saliva · Non-contact removal · Dental plaque . Toothbrushing $\cdot$ Sonic brush

\section{Introduction}

In order to improve the efficacy of oral hygiene, powered toothbrushes have been developed [31]. The benefits of various types of powered toothbrushes over manual brushing are not always evident, but it is clear that powered tooth brushing is at least as effective as manual brushing. Moreover, powered toothbrushes with a rotatingoscillating or sonic action remove plaque and reduce gingivitis significantly more than manual brushes $[3,12$, 21, 29, 37]. Other forms of powered brushes (side to side, counter oscillation, circular, and ultrasonic) produce a less consistent reduction of plaque and gingivitis [28].

Salivary conditioning on surfaces exposed to the oral cavity starts within seconds after exposure to the oral environment and already within the first minute, specific salivary components are detected followed by spatiotemporal adhesion of different bacterial strains and species $[11,23]$ constituting dental plaque in vivo $[33,40]$. Initially, the pellicle is colonized by streptococci and Actinomyces species, after which, bacterial acquisition continues with more pathogenic and commensal strains and species $[15,16,27]$.

In vitro plaque removal studies require biofilm models that resemble in vivo dental plaque [32]. Most studies on dental plaque have focused on single species biofilms, which neglect multi-species interactions as occurring in oral biofilms $[1,17,25]$ and therewith may affect the ease with 
which these model biofilms can be mechanically removed. Moreover, in many models, biofilms are grown under compression, like in the constant depth film fermenter [14] or in the absence of relevant shear, known to affect the morphology and viscoelastic strength of biofilms [35].

The aim of the present in vitro study was to compare different biofilm models (single and dual-species biofilms as well as multi-species biofilms grown from human whole saliva) with respect to their virtues in studying contact and non-contact biofilm removal by different modes of brushing.

\section{Materials and methods}

Bacterial strains, culture conditions, and harvesting

Streptococcus oralis J22, Streptococcus mutans NS, and Actinomyces naeslundii T14V-J1 were used in this study. Streptococci were cultured in Todd-Hewitt broth (THB, OXOID, Basingstoke, UK) in ambient air and A. naeslundii in Schaedler's broth (SB) supplemented with $0.01 \mathrm{~g} / 1$ hemin under anaerobic conditions, both at $37^{\circ} \mathrm{C}$. Strains were precultured in an overnight batch culture and inoculated in a second culture which was grown for $16 \mathrm{~h}$, harvested by centrifugation for $5 \mathrm{~min}$ at $6,500 \mathrm{~g}$, and washed twice with adhesion buffer $(2 \mathrm{mM}$ potassium phosphate, $50 \mathrm{mM}$ potassium chloride, and $1 \mathrm{mM}$ calcium dichloride, $\mathrm{pH}$ 6.8). To break bacterial chains or aggregates, bacteria were sonicated intermittently while cooling on ice for $30-40 \mathrm{~s}$ at $30 \mathrm{~W}$. This procedure was found not to cause cell lysis. Bacteria were diluted in adhesion buffer with $2 \%$ growth medium and $1.5 \mathrm{mg} / \mathrm{ml}$ reconstituted human whole saliva added to a density of $3 \times 10^{8}$ or $1 \times$ $10^{8} \mathrm{ml}^{-1}$ for $A$. naeslundii in co-adhesion experiments (dual-species). A. naeslundii suspension was not supplemented with saliva, as this results in the immediate formation of large aggregates.

Saliva collection and preparation

In order to form a salivary conditioning film, human whole saliva from at least 20 healthy volunteers of both genders was collected into ice-cooled beakers after stimulation by chewing Parafilm ${ }^{\circledR}$. The saliva was pooled, centrifuged, and treated by adding phenylmethylsulfonyl fluoride to a final concentration of $1 \mathrm{mM}$ as a protease inhibitor. The solution was again centrifuged, dialyzed (molecular weight cut-off, 6-8 kD) overnight at $4^{\circ} \mathrm{C}$ against demineralized water, and lyophilized for storage. For experiments, lyophilized saliva was dissolved at a concentration of $1.5 \mathrm{mg} / \mathrm{ml}$ in adhesion buffer. A glass plate was salivacoated by incubating in saliva for $16 \mathrm{~h}$ at room temperature.
All volunteers gave their informed consent to saliva donation and with approval of the Medical Ethical Committee at UMCG, Groningen (M09.069162), The Netherlands.

Freshly collected human whole saliva, from two healthy volunteers, was used as a multi-species source for bacterial adhesion and biofilm growth. In the morning, saliva was stimulated by chewing Parafilm ${ }^{\circledR}$ and collected into icecooled beakers. The bacterial density of thus collected fresh human whole saliva was $3.9 \pm 0.9 \times 10^{8} \mathrm{ml}^{-1}$. The two saliva samples were mixed and diluted 1:1 with adhesion buffer, therewith reducing the bacterial concentration to around $2 \times 10^{8} \mathrm{ml}^{-1}$ for initial adhesion experiments. Filtersterilized, tenfold-diluted, fresh human whole saliva from the same volunteers was employed to stimulate biofilm growth of initially adhering bacteria.

\section{Biofilm formation and brushing}

Bacterial adhesion experiments were performed in a parallel plate flow chamber (dimensions: $1 \times \mathrm{w} \times \mathrm{h}=175 \times 17 \times$ $0.75 \mathrm{~mm}$ ), as previously described [5]. The flow chamber was mounted on the stage of a phase contrast microscope equipped with a $40 \times$ ultra-long working distance objective (Olympus ULWD-CD Plan 40 PL). Biofilms were grown on and images taken from the saliva-coated bottom plate of the flow chamber. The flow chamber, glass slides, and all tubes were sterilized before use. Before each experiment, all tubes and the flow chamber were perfused with adhesion buffer for $30 \mathrm{~min}$ in order to remove possible loose remnants of saliva and allow the system to warm up to $33^{\circ} \mathrm{C}$, a relevant oral surface temperature [34], at which all experiments were performed. Flow rate was kept constant during the experiment at $1 \mathrm{ml} / \mathrm{min}$, corresponding with a wall shear rate of $10 \mathrm{~s}^{-1}$ which represents a moderate oral shear [10].

Experiments were started by switching the flow from buffer to a bacterial suspension or fresh human whole saliva, according to two different protocols:

(A) $2 \mathrm{~h}$ adhesion followed by brushing and

(B) $2 \mathrm{~h}$ adhesion continued by overnight growth resulting in 16-h-old biofilms, followed by brushing.

For co-adhesion experiments, a suspension of $A$. naeslundii was perfused first until a surface coverage of $1 \times 10^{6}$ bacteria $\mathrm{cm}^{-2}$ was reached, after which, flow was switched to buffer for $30 \mathrm{~min}$ and subsequently to $S$. oralis suspension to initiate co-adhesion. The viability of the bacterial suspensions during the first $2 \mathrm{~h}$ of adhesion was checked using Live/Dead stain (BacLight ${ }^{\mathrm{TM}}$, Invitrogen, Breda, The Netherlands) and amounted $97 \%$ on average, while fresh human whole saliva contained $85 \%$ viable bacteria. 
Following protocol $\mathrm{A}$, after $2 \mathrm{~h}$ adhesion, ten images were taken from the saliva-coated bottom plate, corresponding with the areas to be brushed. After taking images, the flow was stopped, the flow chamber dismantled, and the bottom plate removed. The selected areas were brushed with a manual (Oral-B soft indicator Regular 40; Oral-B laboratories, Belmont, CA, USA), electric rotating (Oral-B Professional Care 7850 DLX; Braun GmbH, Kronberg, Germany), or sonic (Oral-B Sonic Complete; Braun GmbH, Kronberg, Germany) brush for $20 \mathrm{~s}$, with the brush attached to a home-made moving tray, involving 20 strokes back and forth. Contact brushing was performed in a wetted state (i.e., with a thin film of water on the bottom plate but bristle tips not immersed) under a weight of $220 \mathrm{~g}$ for the manual, $150 \mathrm{~g}$ for the rotating, and $90 \mathrm{~g}$ for the sonic brush [9, 19, 41]. Subsequently, after re-mounting the bottom plate in the flow chamber, it was filled again with buffer and rinsed for $10 \mathrm{~min}$, after which, ten images of the brushed areas were taken. Protocol A was only done for contact brushing, since previous experiments with noncontact brushing have indicated almost full removal of initially adhering bacteria at 2-mm distance [4, 39].

Following protocol $\mathrm{B}$, after $2 \mathrm{~h}$ adhesion, flow was switched to growth medium (THB for streptococci and co-adhering bacteria, SB for A. naeslundii, and 10\% saliva for bacteria adhering from fresh saliva). The growth medium was perfused through the system without recirculation. The salivary flow rate was $0.5 \mathrm{ml} / \mathrm{min}$ during growth corresponding to a wall shear rate of $5 \mathrm{~s}^{-1}$, to limit the volume of saliva required. After overnight growth, flow was stopped, the flow chamber dismantled, and the bottom plate removed. The selected areas were brushed, and images were taken as described above. Protocol B was done for contact as well as for noncontact brushing. Non-contact brushing was done in an immersed state and with a distance of $2 \mathrm{~mm}$ between the bristle tips and the surface.

Images were analyzed with a Matlab-based counting program to determine the fractional surface coverage of the substratum by adhering bacteria. The percentage removal was subsequently calculated by

$\%$ Removal $=\left(A_{\mathrm{b}}-A_{\mathrm{a}} / A_{\mathrm{b}}\right) \times 100$,

where " $A_{\mathrm{b}}$ " and " $A_{\mathrm{a}}$ " denote the fractional surface coverage before and after brushing, respectively. Note that in these calculations, " $A_{\mathrm{b}}$ " was corrected for removal effects due to opening of the flow chamber prior to brushing and closing.

\section{Statistics}

Statistical analysis and comparison of the different biofilm models and modes of brushing was performed with Students' independent samples $t$ test. Two-way analysis of variance was used for comparison of different biofilm models, combining data for the three modes of contact brushing. A significance level of $p<0.05$ was used.

\section{Results}

In this study, it was chosen to apply a fixed time for adhesion and growth which resulted in different surface coverages by adhering bacteria for the different biofilm models (Table 1). In the 2-h single strain experiments, streptococci adhered in lower surface coverages than Actinomyces, while the surface coverage of bacteria in dual-species ( $S$. oralis $\mathrm{J} 22$ and $A$. naeslundii T14V-J1) adhesion was higher than in multi-species (bacteria from fresh saliva) adhesion. After $16 \mathrm{~h}$ of growth, single strain and dual-species biofilms exhibited similar surface coverages by adhering bacteria, while here too multi-species biofilms yielded a lower surface coverage. In general, handling of the flow chamber caused removal of a nonnegligible number of bacteria, which was corrected for in the calculation of removal percentages. Note that $S$. mutans biofilms adhered so weakly that they could not withstand opening and closing of the flow chamber.

In Fig. 1, the percentage removal due to contact brushing for each mode of brushing is shown for $2 \mathrm{~h}$ adhesion (Fig. 1a) and 16-h-old biofilms (Fig. 1b). The removal percentages were not significantly different for the three modes of brushing and depended solely on the biofilm model considered. All differences observed in percentage removal between the biofilm models were significant, except for dual-species biofilms compared to A. naeslundii as well as multi-species biofilms compared to $S$. mutans.

Non-contact brushing of 16-h-old biofilms, however, revealed distinct differences in removal between different modes of brushing (see Fig. 2). Clearly, electric rotating and sonic brushes perform much better than manual brushing, while a sonic brush only removed more biofilm than an electric rotating brush in case of multi-species biofilms. Interestingly, A. naeslundii biofilms could not be removed in any significant amount, neither by electric rotating nor by sonic brushing. The non-contact removal of A. naeslundii biofilm is significantly lower than the other biofilm models; whereas, dual-species biofilms are removed significantly more than multi-species.

\section{Discussion}

In this study, we compared different in vitro biofilm models in order to study plaque removal. In particular, we compared single strain, dual-species, and multi-species biofilms with respect to their virtues in evaluating biofilm 
Table 1 The fractional surface coverage by adhering bacteria after $2 \mathrm{~h}$ adhesion or $16 \mathrm{~h}$ growth on saliva-coated glass prior to and after opening and closing the flow chamber

\pm denotes the standard deviation over triplicate experiments

${ }^{\text {a }}$ Could not be determined

\begin{tabular}{|c|c|c|c|c|}
\hline \multirow[t]{2}{*}{ Biofilm model } & \multicolumn{2}{|l|}{$2 \mathrm{~h}$ adhesion } & \multicolumn{2}{|l|}{$16 \mathrm{~h}$ growth } \\
\hline & Before opening & After opening & Before opening & After opening \\
\hline S. mutans NS & $0.03 \pm 0.02$ & $0.01 \pm 0.01$ & $-{ }^{\mathrm{a}}$ & $-^{\mathrm{a}}$ \\
\hline S. oralis $\mathrm{J} 22$ & $0.09 \pm 0.02$ & $0.04 \pm 0.01$ & $0.92 \pm 0.07$ & $0.51 \pm 0.06$ \\
\hline A. naeslundii $\mathrm{T} 14 \mathrm{~V}-\mathrm{J} 1$ & $0.18 \pm 0.05$ & $0.18 \pm 0.06$ & $1.00 \pm 0.00$ & $1.00 \pm 0.00$ \\
\hline Dual-species biofilm & $0.13 \pm 0.04$ & $0.09 \pm 0.03$ & $0.89 \pm 0.13$ & $0.42 \pm 0.22$ \\
\hline Multi-species biofilm & $0.01 \pm 0.01$ & $0.01 \pm 0.01$ & $0.29 \pm 0.09$ & $0.28 \pm 0.10$ \\
\hline
\end{tabular}
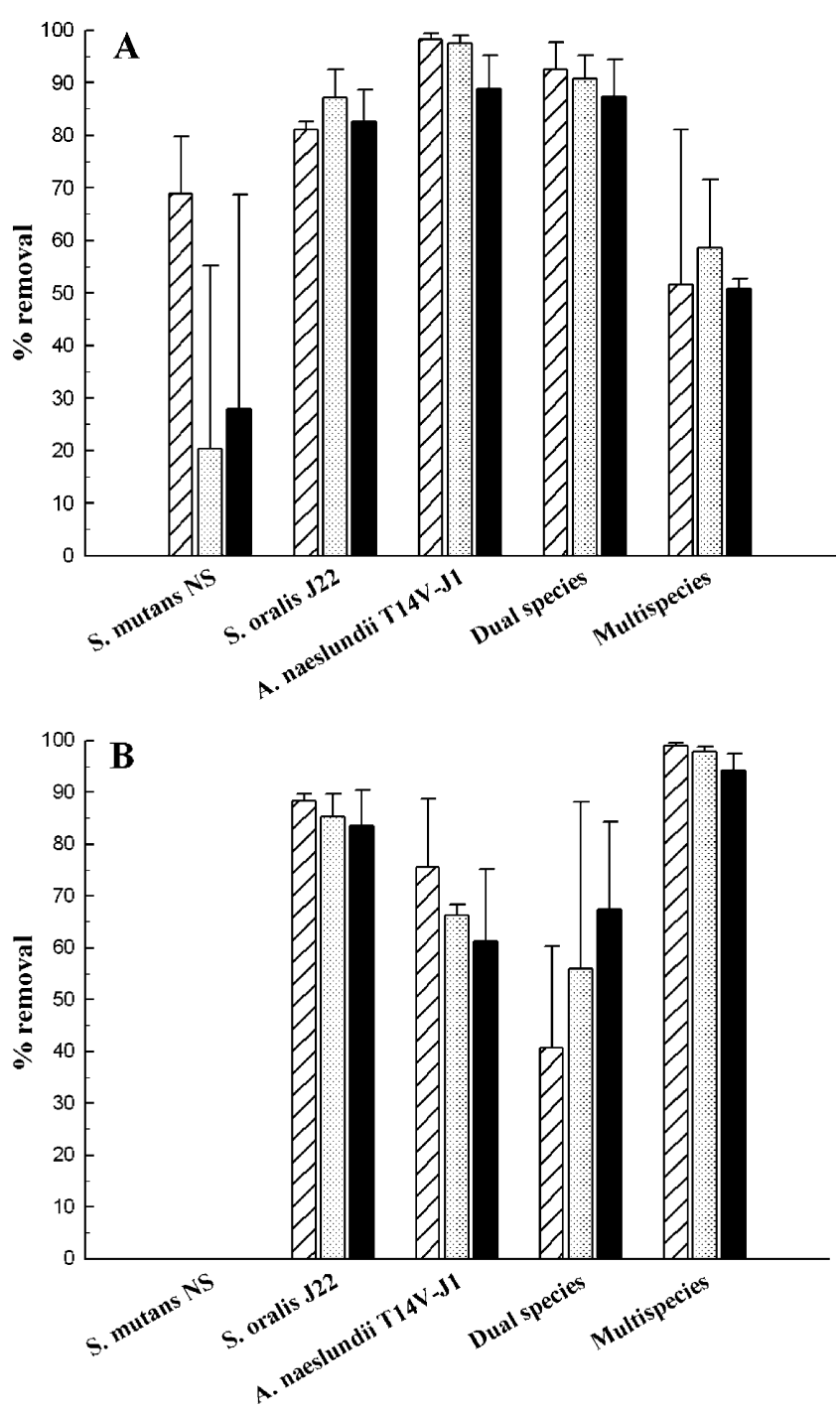

Fig. 1 The percentage removal due to contact brushing by three different modes of brushing and after correcting for handling of the flow chamber. a Two hours adhesion and (b) 16-h-old biofilms. Striped bars represent data for manual brushing, while dotted and black bars are valid for electric rotating and sonic brushes, respectively. Note that no experiments with 16-h-old biofilms could be done with Streptococcus mutans NS due to their weak adhesion. Error bars represent the SD over three experiments with separately cultured bacteria and differently prepared salivary coatings removal by different modes of contact and non-contact brushing. Different modes of contact brushing removed similar percentages of the biofilms, but the adhesion strength judged from removal percentages by the different modes of brushing in the different biofilm models appeared strongly dependent on the bacterial strain and was initially much weaker than after growth. Non-contact removal was slightly more effective for the sonic than for the electric rotating brush, while removal percentages in non-contact removal were always less than in contact removal. It is known from literature that rotating-oscillating and sonicpowered toothbrushes are clinically significantly better than manual brushing [3, 12, 21, 29, 37], while for other forms of powered toothbrushes, consistent results are lacking [28]. Thus, since the differences observed between different modes of contact brushing are insignificant while clinically powered toothbrushes perform better than manual ones, it

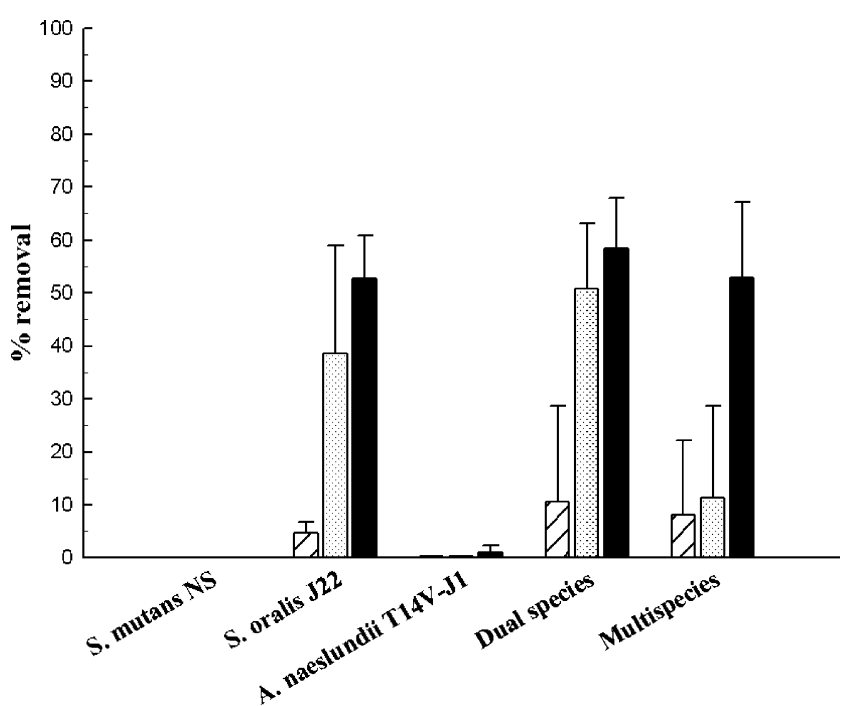

Fig. 2 The percentage removal of 16-h-old biofilms due to noncontact brushing by three different modes of brushing and after correcting for handling of the flow chamber. Striped bars represent data for manual brushing, while dotted and black bars are valid for electric rotating and sonic brushes, respectively. Note that no experiments could be done with Streptococcus mutans NS due to their weak adhesion NS. Error bars represent the SD over three experiments, with separately cultured bacteria and differently prepared salivary coatings 
must be concluded that non-contact brushing adds a clinically relevant contribution to plaque removal in vivo. For the current study, it was chosen to compare brushing modes and biofilm models in the absence of the use of toothpastes, since this allows better focus on mechanical removal mechanisms.

The exact mechanism of non-contact biofilm removal is not known but must involve energy transfer from the brush head to the biofilm where the energy is applied to disrupt the biofilm. Energy transfer could be through direct acoustic means or by vigorous hydrodynamic motion created by the brush head [13, 20]. Interestingly, energy transfer by non-contact brushing is inadequate to cause removal percentages over $60 \%$ (this study; see also [1]), which suggests that non-contact brushing can only make a biofilm thinner but is in its current technology unable to remove bacteria in the base, i.e., the initially adhering bacteria of a biofilm. Removal of bacteria in the base of a biofilm may therefore require direct contact with the bristles, which puts emphasis as well on the applied forces, which were chosen in this study on the basis of clinically reported forces for the different modes of brushing [9, 19, $38,41]$.

In contact brushing, there are some remarkable differences between the biofilm models evaluated. S. mutans biofilms adhere clearly the most weakest, and this is in line with the fact that they are not considered to be initial colonizers of tooth surfaces in vivo and thus have no role in linking the biofilm to the substratum surface [24]. S. oralis and $A$. naeslundii do belong to the group of initial colonizers $[15,16,27]$, and it is of interest to note that on average, their 16-h-old dual-species biofilm adheres the most tenacious (see Fig. 3), even more so than a 16-h-old multi-species biofilm. This is in contrast with the observations on initially adhering bacteria, where multi-species adhesion yields the most tenacious adhesion. Initially, adhering bacteria have not yet had the opportunity to grow and anchor themselves to a substratum through the excretion of extracellular polymeric substance [18], while in addition, they have not been in competition for nutrients with each other, which may lead to the competitive exclusion from the biofilm of some of the initial colonizers. The percentages of Actinomyces in the multi-species and dual-species biofilm are very similar (around $8 \%$ for multispecies [2] and around 10\% for the dual-species biofilm, as microscopically estimated) and, therefore, differences in Actinomyces prevalence can be excluded as a reason.

The multitude of proteins present in human whole saliva and in salivary conditioning films elicits complex interactions with specific adhesins on and between bacteria. Although the adhesion of $S$. mutans is promoted by high molecular weight proteins, agglutinins, these are also responsible for aggregation [6, 7]. In our experiments,

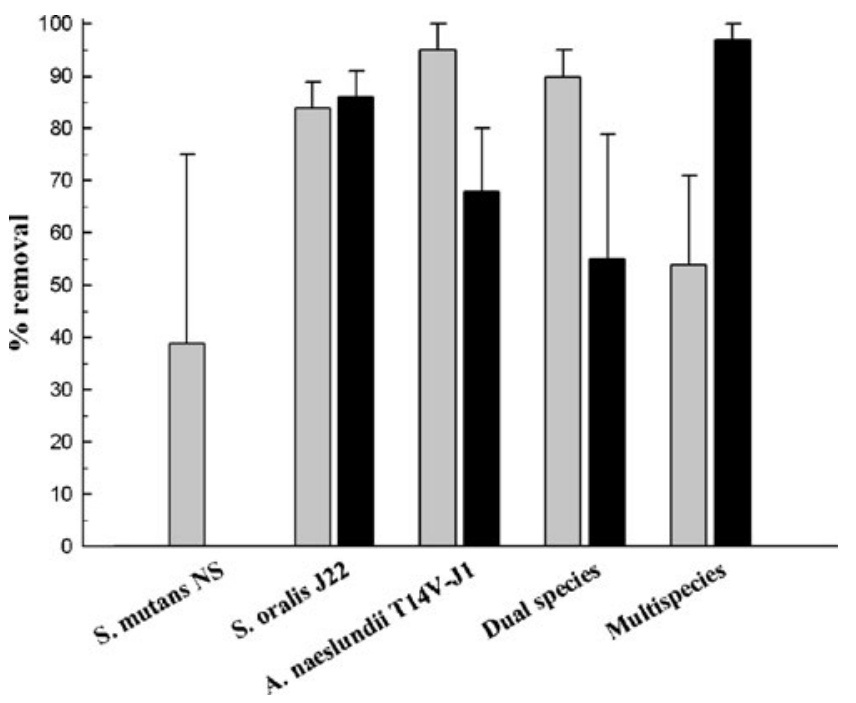

Fig. 3 The percentage removal due to contact brushing, as averaged for all three different modes of brushing and after correcting for handling of the flow chamber. Gray bars represent $2 \mathrm{~h}$ adhesion and black bars denote 16-h-old biofilms. Note that no experiments with 16-h-old biofilms could be done with Streptococcus mutans NS due to their weak adhesion. Error bars represent the SD over the data for the three different modes of brushing involved

large surface aggregates of $S$. mutans were observed which were easily removed from the surface even by opening of the flow chamber, reflecting weak binding. Adhesion of the early colonizers like A. naeslundii and $S$. oralis is promoted by the interaction with the salivary pellicle mucin MG2, proline-rich proteins, and prolinerich glycoproteins [22, 30]. The phosphoprotein-binding type 1 fimbriae of $A$. naeslundii are responsible for binding to the salivary conditioning films and are likely to be involved in the stronger binding of $A$. naeslundii, relative to the one of $S$. oralis $[8,26,36]$. In dual-species biofilms, co-adhesion is mediated by Gal/GalNAc-binding type 2 fimbriae of $A$. naeslundii with a specific streptococcal receptor polysaccharide on $S$. oralis [30, 42]. During growth, A. naeslundii probably strengthens the bonds with the salivary conditioning film and its coadhesion partner, resulting in a strong "initial layer" of bacteria that is difficult to remove. Clearly, this bond strengthening does not take place during 2-h adhesion due to time constraints and lack of nutrient availability.

Summarizing, in an initial adhesion model, multi-species biofilms are most difficult to remove by brushing, while in a more mature biofilm model, i.e., after $16 \mathrm{~h}$ of growth, dual-species biofilms adhere more tenaciously due to the sole presence of the initial colonizers $S$. oralis and A. naeslundii. Although a multi-species biofilm derived from fresh human whole saliva and grown for $16 \mathrm{~h}$ bears the closest similarity to the clinical reality, in vitro, it poses less of a challenge to remove than does a dual-species biofilm. Since moreover, dual-species biofilms are easier to 
grow reproducibly, we believe that these are to be preferred above multi-species biofilms in mechanical plaque removal studies in vitro.

Conflict of interest The authors declare that they have no conflict of interest.

Open Access This article is distributed under the terms of the Creative Commons Attribution Noncommercial License which permits any noncommercial use, distribution, and reproduction in any medium, provided the original author(s) and source are credited.

\section{References}

1. Adams H, Winston MT, Heersink J, Buckingham-Meyer KA, Costerton JW, Stoodley P (2002) Development of a laboratory model to assess the removal of biofilm from interproximal spaces by powered tooth brushing. Am J Dent 15(Spec):12B$17 \mathrm{~B}$

2. Al-Ahmad A, Wunder A, Auschill TM, Follo M, Braun G, Hellwig E, Arweiler NB (2007) The in vivo dynamics of Streptococcus spp., Actinomyces naeslundii, Fusobacterium nucleatum and Veillonella spp. in dental plaque biofilm as analysed by five-colour multiplex fluorescence in situ hybridization. J Med Microbiol 56:681-687

3. Biesbrock AR, Walters PA, Bartizek RD, Goyal CR, Qaqish JG (2008) Plaque removal efficacy of an advanced rotationoscillation power toothbrush versus a new sonic toothbrush. Am J Dent 21:185-188

4. Busscher HJ, Rustema-Abbing M, Bruinsma GM, De Jager M, Gottenbos B, Van der Mei HC (2003) Non-contact removal of coadhering and non-coadhering bacterial pairs from pellicle surfaces by sonic brushing and de novo adhesion. Eur J Oral Sci 111:459-464

5. Busscher HJ, Van der Mei HC (2006) Microbial adhesion in flow displacement systems. Clin Microbiol Rev 19:127-141

6. Carlen A, Olsson J (1995) Monoclonal antibodies against a highmolecular-weight agglutinin block adherence to experimental pellicles on hydroxyapatite and aggregation of Streptococcus mutans. J Dent Res 74:1040-1047

7. Carlen A, Olsson J, Borjesson AC (1996) Saliva-mediated binding in vitro and prevalence in vivo of Streptococcus mutans. Arch Oral Biol 41:35-39

8. Cisar JO, Sandberg AL, Mergenhagen SE (1984) The function and distribution of different fimbriae on strains of Actinomyces viscosus and Actinomyces naeslundii. J Dent Res 63:393-396

9. Danser MM, Timmerman MF, IJzerman Y, Bulthuis H, Van der Velden U, Van der Weijden GA (1998) Evaluation of the incidence of gingival abrasion as a result of toothbrushing. J Clin Periodontol 25:701-706

10. Dawes C, Watanabe S, Biglow-Lecomte P, Dibdin GH (1989) Estimation of the velocity of the salivary film at some different locations in the mouth. J Dent Res 68:1479-1482

11. Hannig M (1999) Ultrastructural investigation of pellicle morphogenesis at two different intraoral sites during a $24-\mathrm{h}$ period. Clin Oral Investig 3:88-95

12. Ho HP, Niederman R (1997) Effectiveness of the Sonicare sonic toothbrush on reduction of plaque, gingivitis, probing pocket depth and subgingival bacteria in adolescent orthodontic patients. J Clin Dent 8:15-19

13. Hope CK, Petrie A, Wilson M (2003) In vitro assessment of the plaque-removing ability of hydrodynamic shear forces produced beyond the bristles by 2 electric toothbrushes. J Periodontol 74:1017-1022

14. Hope CK, Wilson M (2002) Comparison of the interproximal plaque removal efficacy of two powered toothbrushes using in vitro oral biofilms. Am J Dent 15(Spec):7B-11B

15. Kolenbrander PE, Palmer RJ Jr, Rickard AH, Jakubovics NS, Chalmers NI, Diaz PI (2006) Bacterial interactions and successions during plaque development. Periodontol 2000 42:47-79

16. Li J, Helmerhorst EJ, Leone CW, Troxler RF, Yaskell T, Haffajee $\mathrm{AD}$ et al (2004) Identification of early microbial colonizers in human dental biofilm. J Appl Microbiol 97:1311-1318

17. Luppens SB, Kara D, Bandounas L, Jonker MJ, Wittink FR, Bruning $\mathrm{O}$ et al (2008) Effect of Veillonella parvula on the antimicrobial resistance and gene expression of Streptococcus mutans grown in a dual-species biofilm. Oral Microbiol Immunol $23: 183-189$

18. Mayer C, Moritz R, Kirschner C, Borchard W, Maibaum R, Wingender J et al (1999) The role of intermolecular interactions: studies on model systems for bacterial biofilms. Int $\mathrm{J}$ Biol Macromol 26:3-16

19. McCracken GI, Stacey F, Heasman L, Sellers P, Macgregor ID, Kelly PJ et al (2001) A comparative study of two powered toothbrushes and one manual toothbrush in young adults. J Clin Dent 12:7-10

20. McInnes C, Engel D, Martin RW (1993) Fimbria damage and removal of adherent bacteria after exposure to acoustic energy. Oral Microbiol Immunol 8:277-282

21. Moritis K, Delaurenti M, Johnson MR, Berg J, Boghosian AA (2002) Comparison of the Sonicare Elite and a manual toothbrush in the evaluation of plaque reduction. Am J Dent 15(Spec):23B$25 \mathrm{~B}$

22. Murray PA, Prakobphol A, Lee T, Hoover CI, Fisher SJ (1992) Adherence of oral streptococci to salivary glycoproteins. Infect Immun 60:31-38

23. Nieuw Amerongen AV, Veerman ECI, Vissink A (2004) Speeksel, speekselklieren en mondgezondheid. Bohn Stafleu Van Loghum, Houten

24. Nyvad B, Kilian M (1990) Comparison of the initial streptococcal microflora on dental enamel in caries-active and in caries-inactive individuals. Caries Res 24:267-272

25. Palmer RJ, Kazmerzak K, Hansen MC, Kolenbrander PE (2001) Mutualism versus independence: strategies of mixed-species oral biofilms in vitro using saliva as the sole nutrient source. Infect Immun 69:5794-5804

26. Prakobphol A, Burdsal CA, Fisher SJ (1995) Quantifying the strength of bacterial adhesive interactions with salivary glycoproteins. J Dent Res 74:1212-1218

27. Ramberg P, Sekino S, Uzel NG, Socransky S, Lindhe J (2003) Bacterial colonization during de novo plaque formation. J Clin Periodontol 30:990-995

28. Robinson PG, Deacon SA, Deery C, Heanue M, Walmsley AD, Worthington $\mathrm{HV}$ et al (2005) Manual versus powered toothbrushing for oral health. Cochrane Database Syst Rev:CD002281

29. Rosema NA, Timmerman MF, Versteeg PA, van Palenstein Helderman WH, Van der Velden U, Van der Weijden GA (2008) Comparison of the use of different modes of mechanical oral hygiene in prevention of plaque and gingivitis. J Periodontol 79:1386-1394

30. Ruhl S, Sandberg AL, Cisar JO (2004) Salivary receptors for the proline-rich protein-binding and lectin-like adhesins of oral Actinomyces and streptococci. J Dent Res 83:505-510

31. Sicilia A, Arregui I, Gallego M, Cabezas B, Cuesta S (2002) A systematic review of powered vs manual toothbrushes in periodontal cause-related therapy. J Clin Periodontol 29(Suppl 3): $39-54$ 
32. Sissons CH (1997) Artificial dental plaque biofilm model systems. Adv Dent Res 11:110-126

33. Socransky SS, Haffajee AD, Cugini MA, Smith C, Kent RL Jr (1998) Microbial complexes in subgingival plaque. J Clin Periodontol 25:134-144

34. Spierings TA, Peters MC, Plasschaert AJ (1984) Surface temperature of oral tissues. A review. J Biol Buccale 12:91-99

35. Stoodley P, Cargo R, Rupp CJ, Wilson S, Klapper I (2002) Biofilm material properties as related to shear-induced deformation and detachment phenomena. J Ind Microbiol Biotechnol 29:361-367

36. Tang G, Yip HK, Samaranayake LP, Chan KY, Luo G, Fang HH (2004) Direct detection of cell surface interactive forces of sessile, fimbriated and non-fimbriated Actinomyces spp. using atomic force microscopy. Arch Oral Biol 49:727-738

37. Tritten CB, Armitage GC (1996) Comparison of a sonic and a manual toothbrush for efficacy in supragingival plaque removal and reduction of gingivitis. J Clin Periodontol 23:641-648
38. Van der Mei HC, Rustema-Abbing M, Bruinsma GM, De Jager M, Gottenbos B, Busscher HJ (2004) Influence of weight on removal of co-adhering bacteria from salivary pellicles by different modes of brushing. Caries Res 38:85-90

39. Van der Mei HC, Rustema-Abbing M, Bruinsma GM, Gottenbos B, Busscher HJ (2007) Sequence of oral bacterial co-adhesion and non-contact brushing. J Dent Res 86:421-425

40. Van der Velden U, Abbas F, Armand S, Loos BG, Timmerman MF, Van der Weijden GA et al (2006) Java project on periodontal diseases. The natural development of periodontitis: risk factors, risk predictors and risk determinants. J Clin Periodontol 33:540548

41. Van der Weijden GA, Timmerman MF, Versteeg PA, Piscaer M, Van der Velden U (2004) High and low brushing force in relation to efficacy and gingival abrasion. J Clin Periodontol 31:620-624

42. Yoshida Y, Palmer RJ, Yang J, Kolenbrander PE, Cisar JO (2006) Streptococcal receptor polysaccharides: recognition molecules for oral biofilm formation. BMC Oral Health 6(Suppl 1):S12 